\title{
ARTICLE TITLE: CUSTOMER VALUES AND CSR IMAGE IN THE BANKING INDUSTRY
}

\section{RUNNING HEAD: VALUES AND CSR IMAGE}

\begin{abstract}
:
The authors analyse the role that collectivism and novelty seeking play in the formation process of corporate social responsibility (CSR) image in the Spanish banking industry. Two multisampling analyses of a structural equation model are performed on a sample of 1,124 customers. The findings of the paper allow the authors to anticipate CSR image based on (1) the congruence between the company and its CSR initiatives, (2) the attribution of motivations for the company to implement CSR and (3) corporate credibility in developing CSR initiatives. The findings also show that collectivists and innovative customers process information differently to individualists and conservative customers.
\end{abstract}

\section{KEYWORDS:}

CSR image, company-CSR congruence, motivational attribution, corporate credibility, collectivism, novelty seeking

\section{ARTICLE CLASSIFICATION:}

Research paper 


\section{INTRODUCTION}

The banking industry has experienced an important transformation in recent years due to the important changes that have taken place in global markets (Poolthong and Mandhachitara, 2009). Globalisation, deregulation, de-intermediation, financial innovation and the appearance of new technologies that modify the traditional distribution channels of banking services have caused the growing homogenisation of institutions (Flavián et al., 2005). As a result, customers do not currently perceive substantial differences among institutions and the products and banking services that they offer. All of this is compounded by the international business climate of the past decade, marked by frequent financial scandals and questionable accounting and management practices (Piñeiro et al., 2009), leading to the economic crisis of world markets. The results are a loss of societal confidence in the financial system and its institutions and an increase in the social conscience of regulators, shareholders, employees and customers, all of whom demand better tools for the evaluation of business practices (KPMG, 2008).

In this context, it is of vital importance for banking institutions to manage their corporate image so they can differentiate themselves from competitors and regain customer confidence in the efficiency of their businesses (Flavián et al., 2005). In the management of the aforementioned image, corporate social responsibility (CSR) is gaining substantial attention from scholars and practitioners (Rugimbana et al., 2008). CSR refers to company activities that demonstrate the inclusion of economic, social and environmental concerns in business operations and in interactions with stakeholders (van Marrewijk, 2003). In this sense, Rugimbana et al. (2008) 
consider that banks may need to adopt a strategy of maintaining a well-calculated balance between the social and economic aspects of their services to satisfy the needs of banking clients.

Consequently, the banking industry is one of the most proactive investors in CSR (Truscott et al., 2009). In the international realm, for example, there has been a general adoption of CSR principles along with growing investment in social activities. Furthermore, banking institutions have traditionally had the most links to the United Nations Global Compact, representing 9.5\% of 3,700 subscribing businesses in 2008 (CECA, 2008). Similarly, banking institutions are also present in the main sustainability indexes, accounting for more than $11 \%$ of the companies in the FTSE4Good Index and nearly $22 \%$ of those in the Dow Jones Sustainability Index (CECA, 2008).

Nonetheless, and in spite of the recent attention paid to CSR, the study of how customers relate to CSR in the banking industry is still a relatively new line of research and scholars consider that more information on CSR image is still desirable (Maignan, 2001). CSR image refers to customer perceptions of the answer a company gives to its economic, social and environmental concerns (Lai et al., 2010). The authors of this paper consider that the analysis of CSR image among customers is particularly important because although customers know little specific information about banking institutions (such as their financial situation), their feedback is essential because customers are the main source of incomes for companies and also the most decisive group in the search for a positive reputation (Walsh et al., 2009). Furthermore, the interaction that is established among customers through word of mouth is more impactful in business success than corporate advertising and public relations actions (Ruiz et al., 2014). 
Among the papers exploring CSR image, most scholars have focused on studying the impact of CSR image on the behaviour of banking customers. This is so because CSR image is believed to boost customer-related benefits such as satisfaction, repurchase intentions or customer willingness to recommend the company to other consumers (Mason and Simmons, 2002). However, few studies have attempted to understand the process by which customers construct CSR image (Rifon et al., 2004; Becker-Olsen et al., 2006), a fact that hampers the generation of effective managerial strategies based on economic, social and environmental concerns (Rifon et al., 2004).

Among the few papers devoted to the study of the formation process of CSR image, it is even more outstanding that no one has paid attention to the role that psychological characteristics (such as customer values) play when these stakeholders construct their perceptions of CSR image. Nonetheless, when looking at other issues, scholars have demonstrated that customer values determine customer behaviour and cognitive processes (Schwartz, 1992) and several papers find that these psychological characteristics might even be more adequate to understand customer behaviour in a CSR context than demographic features (Laroche et al., 2005). These ideas allow the authors to anticipate that customer values might also significantly affect the way in which customers construct CSR image.

Following the ideas of Adelopo and Cea (2010), the authors of this paper evaluate two customer values that have been closely related to CSR among financial institutions. These values are collectivism (Schwartz, 1992; Laroche et al., 2005) and novelty seeking (Schwartz, 1992; Phau 
and Teah, 2009). Collectivism refers to the customer orientation towards the culture of 'we' and reflects a customer characterised by a self-definition that is dependent upon his/her social context as well as the other people living in it (Laroche et al., 2005). Novelty seeking refers to the customer orientation towards experimentalism and describes a customer who likes trying new things and facing stimulating challenges (Phau and Teah, 2009). Adelopo and Cea (2010) consider that a better understanding of the influence of these two socio-cultural values in customer-company relationships is especially helpful in the quest to understand how banking institutions interact with the community in which they operate, while it also provides interesting insights into how banking institutions should behave to achieve better results among customers.

Based on all these ideas, the authors of this paper aim to describe and test a reliable causal model to understand the way in which customers construct their perceptions of CSR image in the Spanish banking industry. The authors also test the model in four samples of customers with diverse orientations towards collectivism and novelty seeking in order to identify if significant differences exist in the way in which customers construct CSR image. These analyses will generate great value for managers and businesses, which can use the findings of this paper to design more effective CSR and communication strategies based on segmentation.

The paper starts by presenting a conceptual model to understand the formation process of CSR image among banking customers. Secondly, the authors discuss the role of customer personal values (collectivism and novelty seeking) in that process. The third section of the paper shows the research design. In the fourth section, the authors describe the findings of the study. The 
paper ends with a discussion of the most significant conclusions, managerial implications, limitations and future lines of research derived from the study.

\section{LITERATURE REVIEW}

\section{CSR image in the banking industry}

A relatively modern approach to explain CSR image in the banking industry comes from stakeholder theory (Freeman, 1984), which suggests a dimensioning of CSR image according to the main target groups of banking institutions. Along this line, Clarkson (1995) considers that businesses and practitioners manage relationships with stakeholders instead of society as a general concept in order to better address stakeholders' concerns instead of social ones. According to this proposal, the dimensions of CSR image are classified as a function of those stakeholders that most benefit from corporate CSR activities.

Ruiz et al. (2009) consider that banking institutions may have only taken shareholders' interests into consideration, leading to social problems such as the shortage of financing and financial exclusion. However, these scholars believe that this situation has improved over the years, with

banks working to eradicate this problem globally. In this regard, Server and Capó (2009) consider that banking institutions comply with their social responsibility when they incorporate their stakeholders' expectations into their strategic management. Furthermore, Sarro et al. (2007) believe that the implication of banking institutions in CSR activities is an answer to the commitment of these institutions with society that goes far beyond the economic obligation to 
shareholders to also include responsibilities towards other stakeholders such as employees, customers, suppliers, the government, investors and the local community. The most common stakeholders identified in the banking industry are shareholders, customers, employees and society (Goirigolzarri, 2006).

Based on this stakeholder perspective, Pérez et al. (2013) also define the main sources of CSR image in the banking industry. These scholars identify five dimensions of CSR image relating to customer perceptions of CSR: customers, shareholders, employees, society and a general dimension concerning legal and ethical issues, which include corporate responsibilities towards a broad array of stakeholders that, along with the ones already cited, also include governments and the media.

According to Pérez et al. (2013), CSR image in the customer dimension refers to customer perceptions of corporate activities oriented to customers, basically concerning the complete and honest communication of corporate products and services and management of complaints. CSR image in the shareholder dimension is concerned with the evaluation of corporate profitability and information transparency (Soto, 2006; Sarro et al., 2007; Piñeiro et al., 2009). CSR image in the employee dimension covers issues regarding job creation and employment opportunities in the banking industry (Abad, 2002; Pérez et al., 2013). CSR image in the society dimension refers to customer perceptions of issues such as corporate contribution to charity, community development and environmental protection. Finally, the general dimension of CSR image includes customer perceptions of ethical and legal concerns, which refer to broad corporate 
responsibilities that do not benefit specific stakeholders but rather all of them to the same extent (Maignan et al., 1999; Maignan, 2001).

\section{The formation process of CSR image}

For the purpose of this research, the authors use the widely accepted model proposed by Rifon $e t$ al. (2004) to understand how customers generally form their perceptions of CSR image. In this regard, it is well known that nowadays it is common for companies to associate their products and brands with other external objects they believe to be positively valued by customers. The aim of this strategy is to cause a positive image transfer from the external attribute to the company (Nan and Heo, 2007). For example, in sponsorship the brand is associated with a prestigious event; a celebrity endorsement matches the product with a known public figure; the brand extension strategy links a new product with an existing reputable brand; and in causerelated marketing, the product is associated with a non-profit-making organisation or a social cause to which stakeholders have a positive attitude (Varadarajan and Menon, 1988).

Nevertheless, scholars have suggested that the transfer does not occur equally in all situations and that diverse circumstances mediate the formation of CSR image (Becker-Olsen et al., 2006). Rifon et al. (2004) propose a causal model that explains the effect of company-CSR congruence, the attribution of corporate motivations to engage in CSR and corporate credibility on customer attitudes towards CSR. The results of this study confirm the value of a company's involvement in sponsoring CSR initiatives, which are perceived by customers as 1) consistent with the core business activities and personality (company-CSR congruence), 2) altruistic in nature 
(motivational attribution) and 3) credible (corporate credibility). First, congruence generates stronger customer attributions of altruistic corporate motivations, credibility and customer attitude towards the company than incongruence does. Secondly, customer perceptions of corporate altruistic motivations mediate the relationship between congruence and credibility. Finally, credibility perceptions mediate the relationship between corporate motive assessment and customer attitude. Table 1 summarises previous papers that have confirmed the adequacy of this model in diverse research contexts.

\section{Table 1 about here}

Despite this body of work, Rifon et al. (2004) argue that feasible moderating effects on the formation process of customer perceptions of CSR image have been ignored in the literature. Based on both theoretical and empirical evidence, in this paper the authors propose examining the role of the customer orientation towards collectivism and novelty seeking when these stakeholders form their perceptions of CSR image. A justification of the analysis of these customer characteristics is included in the following section.

\section{The role of customer values in the formation process of CSR image}

Scholars have demonstrated that customer psychological characteristics such as personality, values and lifestyles are of great relevance within the marketing field because they facilitate the identification of different types of customers with diverse behaviours and cognitive processes (Dorsch et al., 2000). Specifically, customer values are some of the most used psychological 
variables for the segmentation of markets, and they have become a recurring topic of study in the marketing literature (Fraj and Martinez, 2006; Bigné et al., 2009). Nevertheless, in the context of this research, new information is needed because there are still no studies applying customer values to better understand how customers construct CSR image.

In this paper, the authors rely on the extensively accepted proposal of Triandis et al. (1985) to analyse the role that collectivism and novelty seeking play in the formation process of CSR image from a customer perspective (Adelopo and Cea, 2010). Triandis et al. (1985) identify four values that are relevant to understanding customer behaviour and organise them as conceptually opposed values in two bipolar continuums. Following the ideas of Schwartz (1992), they differentiate collectivism vs. individualism and novelty seeking vs. conservatism. Triandis et al. (1985) consider that customers will be either collectivists or individualists, or innovative or conservative, but never both at the same time. Based on this idea, the analysis of a single concept in each continuum would be enough to understand customer values because a low representation of the analysed characteristic in the customer value schema means that the customer is more closely oriented towards the opposite personal value (Adelopo and Cea, 2010). In this paper, the authors choose to study collectivism and novelty seeking because both characteristics are believed to be more closely related to CSR image than the opposite values (Wang et al., 2005; Phau and Teah, 2009; Adelopo and Cea, 2010). 


\section{Collectivism}

First, the collectivism/individualism dimension is closely linked to the study of culture in social sciences and it has been especially used to analyse behavioural differences between customers from different cultures, countries and regions (Yoo, 2009; Adelopo and Cea, 2010). Specifically, some countries have demonstrated greater collectivism and they abide by the culture of 'we', while other countries are more individualist because customers are characterised by following the philosophy of 'I' (Hofstede, 1983). Individualists act as autonomous institutions and always look for the full satisfaction of personal objectives (Laroche et al., 2005). Nonetheless, several scholars have also highlighted the limitations of this cultural indicator given its high level of aggregation, which does not allow researchers to identify significant differences at the individual level (Yoo, 2009). Therefore, the analysis of the differences between customers in the same culture is especially relevant for a more precise market classification (Laroche et al., 2005).

In this regard, numerous scholars point to the importance of collectivism when attempting to define the CSR orientation of customers in the same cultural context (Vitell et al., 2003; Laroche et al., 2005; Waldman et al., 2006). For example, Waldman et al. (2006) find that customers who especially value institutional collectivism, which highlights the need for society to promote the equal distribution of resources among the community and emphasise teamwork and group rewards, understand CSR as a multidimensional construct and are also more concerned about CSR issues than individualists. Similarly, Vitell et al. (2003) determine that collectivists have a greater CSR orientation than individualists. In this line, Adelopo and Cea (2010) also hypothesise that disclosure demands in the banking industry are higher among collectivists, 
while the demands for CSR information are lower among individualist customers. Finally, Laroche et al. (2005) demonstrate that information processing is significantly different between collectivists and individualists. Collectivists use a more holistic mechanism of information processing than individualists and evaluate a greater amount of heuristics when analysing CSR.

In line with these ideas, the authors propose the first research hypothesis to evaluate the moderating role of collectivism in the formation process of CSR image. It is proposed that collectivists understand CSR concerns more fully and, hence, are more concerned about CSR than individualists. Thus, differences are expected in the way in which both types of customers build their perceptions of CSR image. Nonetheless, since the moderating role of this customer value in the formation process of CSR image has not been tested in previous academic works, the authors do not anticipate specific orientations for each relationship in the causal model. Thus, the authors formulate their hypothesis broadly:

\section{H1: Collectivism moderates the formation process of CSR image.}

Novelty seeking

The validity of novelty seeking for market segmentation has been widely confirmed, mainly in areas related to technological innovation and new information and communication technologies (Chan and Leung, 2005). However, given its more indirect relationship with CSR, especially compared with values such as collectivism and individualism, this is one of the least-analysed values in the literature related to CSR so far. Nevertheless, the authors consider that the 
unconsolidated position of CSR in the Spanish banking industry is especially relevant and might determine the role of novelty seeking in the formation process of CSR image among customers.

In this regard, even though banking institutions have been related to CSR since the 1950s, greater concern about social, environmental, ethical and legal responsibilities has risen in the past two decades (Marín and Ruiz, 2007). Since the creation of the UN Global Compact in 1999, several public and private frameworks have been developed concerning CSR (e.g., GRI). Several stock market sustainability indexes (e.g., FTSE4Good) and public opinion rankings (e.g., MORI) have also been created. As a consequence, the CSR information available to society has significantly increased in recent decades and banking customers now face a new business paradigm where so much information is provided that it might even be difficult to process. Thus, even though much information exists, it is quite probable that CSR is not fully extended through the whole society yet because not all customers have to be necessarily interested in devoting time and effort to search for, select and evaluate that much data. This fact brings to mind the possibility that CSR initiatives only reach those individuals especially interested in the most current topics and latest novelties in the banking industry. These people may dedicate more effort and resources to informing themselves about CSR in order to make a more objective decision, based on a solid review of the different scopes and determining factors of CSR. On the contrary, conservative customers do not need as much information about a topic that does not catch their attention. Therefore, they might shape a less thoughtful CSR image.

These ideas allow the authors to propose a second research hypothesis aimed at detecting the role of novelty seeking in the formation process of CSR image. Specifically, it is proposed that 
significant differences exist between innovative and conservative customers in the way in which they form their perceptions of CSR image. As previously discussed in the paper, the authors propose the research hypothesis broadly, because no previous research has explored this customer value in relation to CSR image:

\section{H2: Novelty seeking moderates the formation process of CSR image.}

Figure 1 presents the causal model and moderating effects tested in the paper.

\section{Figure 1 about here}

\section{RESEARCH DESIGN}

To test the hypotheses, a study based on personal surveys of the customers of banking services in Spain was conducted. The Spanish banking industry was selected as the context for the research because of the difficulties it has faced overcoming the international economic crisis. It is also an interesting research scenario because since the beginning of the crisis in 2007, society has devoted increasing attention to CSR in this sector (Pérez and Rodríguez del Bosque, 2012). The crisis has led to the loss of society's confidence in banking institutions and an increased social conscience of stakeholders who now demand better tools to evaluate business practices (KPMG, 2008). Thus, the authors of the paper anticipate that concepts such as company-CSR congruence, motivational attribution and corporate credibility might play a determining role in the formation of customer perceptions of CSR image in the banking industry, as proposed by Rifon et al. 
(2004) previously. Nevertheless, CSR image in the banking industry has been scarcely analysed by scholars so far (Pérez and Rodríguez del Bosque, 2012) and the authors believe that new and useful implications could be derived from the specific study of Spanish banking institutions.

Four multisampling analyses were performed. The stages in which the process was divided are presented next.

Measurement scales. Seven-point Likert-type scales (1=strongly disagree with the sentence, $7=$ strongly agree) were used to measure all the concepts in the model (see appendix). First, a four-item scale based on previous proposals by Lafferty et al. (2004) and Bigné et al. (2009) was developed to measure company-CSR congruence, which refers to the similarity between CSR initiatives and corporate personality. Motivational attribution was measured by means of a fouritem scale oriented to identifying customer perceptions of the egoistic or altruistic nature of companies in developing their CSR initiatives. In designing the scale, the works of Becker-Olsen et al. (2006) and Bigné et al. (2009) were taken as references. Corporate credibility was measured by using the proposal of Newell and Goldsmith (2001). Thus, a four-item scale was used where two items measured corporate expertise in CSR and two items measured corporate trustworthiness. CSR image was measured by using the stakeholder-based scale proposed by Pérez et al. (2013). The scale comprises 22 items gathered in five dimensions: customers, shareholders and supervising boards, employees, society and a general dimension concerning legal and ethical issues, which include corporate responsibilities towards a broad array of stakeholders. A detailed explanation of the development of the scale can be found in Pérez et al. (2013). A six-item scale was developed to measure customer collectivism based on universalism 
and benevolence (Schwartz, 1992). Finally, novelty seeking was measured by means of a fouritem scale that evaluated customer stimulation and self-direction, that is, customer preference for having an exciting life, engaging in stimulating activities and trying new things (Fraj and Martínez, 2006).

Sample profile and segmentation. A non-probabilistic sampling procedure was used to select respondents for the survey. Respondents were customers of banking services over 18 years of age who lived in Cantabria (a medium-sized region in the north of Spain). Banking service customers are people who have at least one bank account for which they are the main decision makers. These customers represent $91.6 \%$ of the population in Spain, according to data from the World Bank Survey. With the purpose of guaranteeing a more accurate representation of the data, multistage sampling by quotas was used based on customer gender and age. After the collection and processing of information, 1,124 valid surveys remained (response rate $=93.7 \%$ ). The global sample was $48.5 \%$ male and $51.5 \%$ female, which was comparable to the population in the country (Instituto Nacional de Estadística, data up to January 1, 2009) with 49\% female and $51 \%$ male. Regarding age, $46.6 \%$ of customers in the sample were under $44(50.1 \%$ in the national population), $31.7 \%$ were between 45 and 64 (29.7\% in the national population) and $21.7 \%$ were over 64 (20.2\% in the national population). This global sample was also segmented according to collectivism and novelty seeking. Customers were assigned to either a low or high cluster depending on the strength of the manifestation of each of these characteristics in their value structure. Collectivists represented $62 \%$ of the population in the sample while individualists were $38 \%$. Innovative customers were $41 \%$ and conservatists were $59 \%$. 
Estimation of the multisampling models. Two multisampling analyses (one for collectivism and one for novelty seeking) were performed. For that purpose, a three-step process was developed to estimate Rifon et al.'s (2004) model in each subsample (collectivists, individualists, conservative and innovative customers) and compare the results. First, the multisampling analyses were performed and a multigroup solution of causal relationships obtained to understand the formation process of CSR image among customers. The purpose of this first step was to determine the standardised coefficients of the six relationships of the model in each subsample. A second step consisted of the test of the factorial invariance of the structural equation model among the categories of customers in each multisampling analysis (collectivists vs. individualists; innovative vs. conservative customers). The purpose of this step was to ensure that the latent constructs (company-CSR congruence, motivational attribution, corporate credibility and CSR image) were understood in the same way among customers with different psychological characteristics and thus the model was comparable among them. The factorial invariance was studied through the Lagrange multiplier (LM) test, which allowed the authors to compare the chi-square differences of the relationships when the restriction concerning the equality among the factorial lambdas in the diverse customer categories in each multisampling analysis was eliminated. When the results of this analysis showed non-significant values in the improvement of the chi-square ( $p>0.05$ for a $95 \%$ confidence level), the factorial invariance was confirmed. Finally, the third step of the analyses consisted of estimating the structural invariance of the model among all the customer categories in each multisampling test. This property was evaluated by recalculating the causal model including the restriction that the standardised betas of the relationships between all the latent constructs were equal among customer categories. Again, the suitability of this restriction was tested with the LM test. This time, it was necessary that the chi- 
square differences were significant $(\mathrm{p}<0.05$ for a 95\% confidence) to confirm that each customer's psychological characteristics were a moderator of the relationship under scrutiny.

\section{FINDINGS}

Validation of the measurement scales. Before proceeding to the analysis of the hypotheses, the reliability, validity and goodness of fit of the scales were globally tested to ensure that the model

fitted the data properly. For this purpose, the authors implemented a first-order confirmatory factor analysis (CFA) with all the latent constructs and taking into consideration the global sample in the study. The results of the CFA are presented in Table 2. Although the SatorraBentler $\chi^{2}$ was significant $(\mathrm{S}-\mathrm{B} \chi 2=568.68$, $\mathrm{p}$-value $<0.05)$, because of the large sample used in the analysis (over 200 cases), all the comparative fit indexes (NFI, NNFI, CFI and IFI) exceeded the minimum recommended value of 0.90 , demonstrating an adequate fit of the model. In addition, the standardised lambdas obtained for company-CSR congruence, motivational attribution, corporate credibility and CSR image were significant and greater than 0.50 , ensuring the convergent validity of the model. Finally, the authors evaluated the discriminant validity of the factorial structure, estimating the confidence intervals for the correlation between pairs of constructs. The results verified the discriminant validity of the model because no confidence interval included the digit 1.

Table 2 about here 
Hypotheses testing. Regarding the findings of the multisampling analyses, first the factorial invariance of the model was confirmed in the two analyses performed ( $p>0.05$ in $100 \%$ of the lambdas compared for collectivism and novelty seeking), which demonstrated that the model was appropriate to understand the formation process of CSR image among all the different types of customers independently consulted. Table 3 presents the results of the multisampling analyses implemented for collectivism and novelty seeking. The findings concerning the models in each customer category, the LM test of the structural invariance and the goodness of fit of the final model (once the model restrictions had been eliminated) are included in the table. Based on the significance of the chi-square differences included in Table 3, the results show that both collectivism (Dif. $\chi^{2}=5.25, \mathrm{p}<0.1$ ) and novelty seeking (Dif. $\chi^{2}=15.50, \mathrm{p}<0.05$ ) moderate the formation process of CSR image. Thus, $\mathrm{H} 1$ and $\mathrm{H} 2$ are supported. Nonetheless, considerable differences exist regarding the predicting value of both these psychological characteristics.

\section{Table 3 about here}

For example, regarding collectivism one significant difference is observed between collectivists and individualists in the effect of corporate credibility on CSR image $\left(\beta_{\text {individualists }}=0.09, p>0.05\right.$ vs. $\beta_{\text {collectivists }}=0.28, \mathrm{p}<0.05$; Dif. $\chi^{2}=$ n.a.). For customers who score below the mean in this personal value, corporate credibility does not significantly influence CSR image $\left(\beta_{\text {individualists }}=0.09, \mathrm{p}>0.05\right)$. On the contrary, for collectivists, corporate credibility is a determining construct $\left(\beta_{\text {collectivists }}=0.28, \mathrm{p}<0.05\right)$ that is additional to company-CSR congruence $\left(\beta_{\text {collectivists }}=0.22, \mathrm{p}<0.05\right)$ and motivational attribution $\left(\beta_{\text {collectivists }}=0.27, \mathrm{p}<0.05\right)$ in the formation 
process of CSR image. Nonetheless, none of the other five relationships in the model are moderated by a customer orientation towards collectivism (Dif. $\chi^{2}, \mathrm{p}>0.05$ ).

Novelty seeking moderates the formation process of CSR image to a larger extent than collectivism (Dif. $\chi^{2}=15.50 ; \mathrm{p}<0.05$ ). Specifically, customers with diverse orientations towards novelty seeking exhibit significant differences regarding the impact that company-CSR congruence has on CSR image ( $\beta_{\text {conservative }}=0.30, p<0.05$ vs. $\beta_{\text {innovative }}=0.21, p<0.05$; Dif. $\chi^{2}=3.50$, $\mathrm{p}<0.1)$, in the effect of motivational attribution on corporate credibility $\left(\beta_{\text {conservative }}=0.42, \mathrm{p}<0.05\right.$ vs. $\beta_{\text {innovative }}=0.55, \mathrm{p}<0.05$; Dif. $\left.\chi^{2}=3.32, \mathrm{p}<0.1\right)$ and $\operatorname{CSR}$ image $\left(\beta_{\text {conservative }}=0.27, \mathrm{p}<0.05\right.$ vs. $\beta_{\text {innovative }}=0.15, \mathrm{p}<0.05$; Dif. $\left.\chi^{2}=8.02, \mathrm{p}<0.05\right)$ and in the impact of corporate credibility on CSR

image $\left(\beta_{\text {conservative }}=0.14, \mathrm{p}>0.05\right.$ vs. $\beta_{\text {innovative }}=0.42, p<0.05$; Dif. $\chi^{2}=$ n.a. $)$. No significant differences are observed in the effect of company-CSR congruence on motivational attribution $\left(\beta_{\text {conservative }}=0.32, \mathrm{p}<0.05\right.$ vs. $\beta_{\text {innovative }}=0.18, \mathrm{p}<0.05$; Dif. $\left.\chi^{2}=1.61, \mathrm{p}>0.05\right)$ or on corporate credibility ( $\beta_{\text {conservative }}=0.45, p<0.05$ vs. $\beta_{\text {innovative }}=0.34, p<0.05$; Dif. $\left.\chi^{2}=0.69, p>0.05\right)$.

\section{DISCUSSION and CONCLUSIONS}

The purpose of this empirical research was to clarify the process that leads customers to construct a certain CSR image of banking institutions. Some research had been devoted to analysing this process but new information regarding the way in which psychological characteristics influence customer perceptions of CSR image was needed. In this regard, this paper contributes to the literature by including the analysis of the moderating role of two 
psychological characteristics, collectivism and novelty seeking, into the academic literature studying the formation process of CSR image.

The findings of the paper confirm the adequacy of Rifon et al.'s (2004) model for understanding the formation process of CSR image, especially among collectivists and innovative banking customers. These customers anticipate CSR image based on three variables: the congruence between CSR initiatives and corporate personality, the attribution of motivations for the company to implement CSR activities and its corporate credibility in developing CSR initiatives. On the contrary, conservative customers only evaluate company-CSR congruence and motivational attribution when constructing CSR image, while credibility is irrelevant for them. Along this line, it is also observed that company-CSR congruence and motivational attribution are more relevant for conservative than innovative customers when constructing CSR image.

The authors believe these results are closely connected to the context in which the research was carried out. In this regard, since 2007 the Spanish banking industry has lost trust because of frequent financial scandals and poor corporate governance practices. Furthermore, in the past decade most banking institutions have diverted their attention towards activities scarcely related to their business and expertise scopes, such as building societies massively investing in the real estate sector (Pérez and Rodríguez del Bosque, 2012). Thus, it makes sense that conservative customers are not willing to take risks when evaluating CSR and only rely on those two concepts that have been the weaknesses of banking institutions during the financial crisis: company-CSR congruence and motivational attribution. Innovative customers follow a more comprehensive 
approach and place greater value on whether companies are expert and trustworthy when implementing CSR.

In the case of individualists, it is observed that most of the relationships in the causal model are not significantly different to those for collectivists. Thus, collectivism is not as good as novelty seeking for identifying differences in the formation process of CSR image. Although these findings contradict the expectations of the authors, it is observed that some previous scholars have found similar results. For example, Adelopo and Cea (2010) find that there is indeed no relationship between the individualist/collectivist cultural dimension and CSR disclosures by the banks in their sample. Thus, also at the cultural level, it seems that individualism/collectivism is not the best predictor of corporate CSR behaviour or customer perceptions of CSR image.

Anyway, for all customers there is a direct relationship between the corporate motivations perceived by the customers of banking services and corporate credibility. In this way, and in accordance with the proposals of attribution theory (Weiner, 1980), this study shows that when the customer of a banking institution perceives that the company has altruistic, extrinsic or ethical motivations when designing and implementing its CSR initiatives, the institution is more credible and customers perceive a more positive CSR image. By contrast, a banking institution loses credibility when it is perceived as egoist, such as when customers anticipate intrinsic motivations for carrying out social activities and believe that CSR is seeking not the public benefit of the stakeholders but the private benefit of the institution. The loss of credibility contributes to the deterioration of CSR image, which, as an essential component of corporate 
image, can have direct consequences on corporate reputation as well as indirect effects on customer satisfaction, retention or identification with the company.

As a key element of facilitating the attribution of altruistic motivations and improving the credibility of the CSR activities of banking institutions, it is essential that there is coherence between corporate personality and the CSR initiatives conducted. It has been shown that when it makes sense to customers that their banking institution performs CSR initiatives, customers have a higher perception of the company's CSR motivations and of its credibility. Therefore, CSR initiatives consistent with corporate goals help improve CSR image. This proposal confirms associative learning theories (Shimp et al., 1991), arguing that association with CSR can transfer meaning to the banking institution itself.

\section{MANAGERIAL IMPLICATIONS}

It is noteworthy that previous scholars have highlighted the contextual nature of CSR, which should be consciously defined, designed and operated within organisations attending to their core business and scope (Campbell, 2007). In this line, Adelopo and Cea (2010) consider that turning CSR research lenses onto banks is timely and should be immensely beneficial to academia, practitioners and policymakers with interest in this area, because the current debate in the literature suggests that CSR expectation, image and performance is a function of the nature of the institutions and sectors of the firms' operations. Specifically, the banking industry in Europe is undertaking significant changes that might be determining customer perceptions of CSR activities. In this regard, it stands to reason that service users now pay special attention to the 
activities of banking providers, asking for them to be congruent and to be justified by the characteristics of the institution that implements them. Activities inconsistent with the philosophy, character and business activity of a banking institution may arouse customer suspicion, negatively affecting corporate image.

The findings in this paper allow managers to design personalised relationships with diverse kinds of customers depending on their value schema and perceptions of CSR image. These results have important implications for companies that face the need to adapt their CSR and communication strategies in an adequate manner to address the different formation processes of CSR image used by customers. In line with the propositions of the relationship marketing perspective, personalising CSR and communication strategies will improve the efficiency and positive outcomes of CSR initiatives, such as customer satisfaction and loyalty. In this regard, the role of company-CSR congruence, motivational attribution and corporate credibility on CSR image must be clarified based on the customer categories analysed in this paper. It has been observed that both collectivists and innovative banking customers organise their CSR image mostly around corporate credibility (expertise and trustworthiness), while individualists and conservative customers place more importance on company-CSR congruence and motivational attribution. These ideas must be reflected in the way in which banking institutions relate to their customers. 


\section{LIMITATIONS AND FUTURE LINES OF RESEARCH}

Some limitations of this paper must be admitted. In this regard, the fact that data were gathered from customers in a single country may limit the generalisation of the findings to other research contexts. The fact that the authors did not control for the influence of diverse information sources on customer perceptions also makes it necessary that readers interpret the findings with caution.

Some future lines of research are highlighted. On the one hand, the exploratory character of the research hypotheses should be refined by future scholars by building consistent theories to justify specific orientations for the mediating effects of collectivism and novelty seeking on the formation process of customer perceptions of CSR image. On the other hand, the special relevance of personal characteristics when explaining differences in the formation process of CSR image brings into consideration the possibility that personal characteristics have significant moderating effects on other cognitive and emotional processes such as, for example, customer affective and behavioural responses to CSR image. In addition, using longitudinal as well as cross-cultural research is recommended because this would allow researchers to test the value of collectivism and novelty seeking as moderators of customer cognitive and emotional processes at different stages of the consolidation process of CSR image and in diverse research settings.

\section{REFERENCES}

Abad, F. (2002) Ocho claves de la acción social empresarial en España. Harvard Deusto Marketing y Ventas 51: 46-51. 
Adelopo, I.A. and Cea, R. (2010) Time and country specific institutional effects on corporate social disclosure by financial institutions: Evidence from fourteen European countries. SSRN Working Paper Series December.

Becker-Olsen, K.L., Cudmore, B.A. and Hill, R.P. (2006) The impact of perceived corporate social responsibility on consumer behavior. Journal of Business Research 59(1): 46-53.

Bigné, E., Currás, R. and Sánchez, I. (2009) Brand credibility in cause-related marketing: The moderating role of consumer values. Journal of Product and Brand Management 18(6): 437-447. Campbell, J.L. (2007) Why would corporations behave in socially responsible ways? An institutional theory of corporate social responsibility. The Academy of Management Review 32(3): 946-967.

CECA (2008) Libro verde de la responsabilidad social corporativa en el sector financiero. Conferencia Española de Cajas de Ahorro.

Chan, J.K. and Leung, L. (2005) Lifestyles, reliance on traditional news media and online news adoption. New Media and Society 7(3): 357-382.

Clarkson, M.B.E. (1995) A stakeholder framework for analyzing and evaluating corporate social performance. The Academy of Management Review 20(1): 92-117.

Dorsch, M.J., Grove, S.J. and Darden, W.R. (2000) Consumer intentions to use a service category. Journal of Services Marketing 14(2): 92-117.

Flavián, C., Guinalíu, M. and Torres, E. (2005) The influence of corporate image on consumer trust: A comparative analysis in traditional versus internet banking. Internet Research 15(4): $447-470$. 
Fraj, E. and Martínez, E. (2006) Environmental values and lifestyles as determining factors of ecological consumer behavior: An empirical analysis. Journal of Consumer Marketing 23(3): 133-144.

Freeman, R.E. (ed.) (1984) Strategic management: A stakeholder approach. Boston, MA: Pittman.

Goirigolzarri, J.I. (2006). La responsabilidad social en el sector financiero: el BBVA. Working paper, Fundación Carolina.

Hofstede, G. (1983) The cultural relativity of organizational practices and theories. Journal of International Business Studies 14(2): 75-89.

KPMG (2008) KPMG international survey of corporate responsibility reporting 2008. Available at http://www.kpmg.com/.

Lafferty, B.A., Goldsmith, R.E. and Hult, G.T.M. (2004) The impact of the alliance on the partners: A look at cause-brand alliances. Psychology \& Marketing 21(7): 509-531.

Lai, C.S., Chiu, C.J., Yang, C.F. and Pai, D.C. (2010) The effects of corporate social responsibility on brand performance: The mediating effect of industrial brand equity and corporate reputation. Journal of Business Ethics 95(3): 457-469.

Laroche, M., Kalamas, M. and Cleveland, M. (2005) 'I' versus 'we': How individualists and collectivists use information sources to formulate their service expectations. International Marketing Review 22(3): 279-308.

Maignan, I. (2001) Consumers' perceptions of corporate social responsibilities: A cross-cultural comparison. Journal of Business Ethics 30: 57-72.

Maignan, I., Ferrell, O.C. and Hult, G.T. (1999) Corporate Citizenship: Cultural Antecedents and Business Benefits. Journal of the Academy of Marketing Science 27(4): 455-469. 
Marín, L. and Ruiz, S. (2007) I need you too! Corporate identity attractiveness for consumers and the role of social responsibility. Journal of Business Ethics 71(3): 245-260.

Mason, C. and Simmons, J. (2012) Are they being served? Linking consumer expectation, evaluation and commitment. Journal of Services Marketing 26(4): 227-237.

Nan, X. and Heo, K. (2007) Consumer responses to corporate social responsibility (CSR) initiatives: Examining the role of brand-cause fit in cause-related marketing. Journal of Advertising 36(2): 63-74.

Newell, S.J. and Goldsmith, R.E. (2001) The development of a scale to measure perceived corporate credibility. Journal of Business Research 52(3): 235-247.

Pérez, A. and Rodríguez del Bosque, I. (2012) The role of CSR in the corporate identity of banking service providers. Journal of Business Ethics 108(2): 145-166.

Pérez, A., Martínez, P. and Rodríguez del Bosque, I. (2013) The development of a stakeholderbased scale for measuring corporate social responsibility in the banking industry. Service Business 7(3): 459-481.

Phau, I. and Teah, M. (2009) Devil wears (counterfeit) Prada: A study of antecedents and outcomes of attitudes towards counterfeits of luxury brands. Journal of Consumer Marketing 26(1): 15-27.

Piñeiro, J., Romero, N. and Vizcaíno, M. (2009) Riesgo de reputación y responsabilidad social empresarial en el sector financiero. La inversión socialmente responsable. Ecosostenible 57: 416.

Poolthong, Y. and Mandhachitara, R. (2009) Customer expectations of CSR, perceived service quality and brand effect in Thai retail banking. The International Journal of Bank Marketing 27(6): 408-427. 
Rifon, N.J., Choi, S.M., Trimble, C.S. and Li, H. (2004). Congruence effects in sponsorship: The mediating role of sponsor credibility and consumer attributions of sponsor motive. Journal of Advertising 33(1): 29-42.

Rugimbana, R., Quazi, A. and Keating, B. (2008) Applying a consumer perceptual measure of corporate social responsibility: A regional Australian perspective. The Journal of Corporate Citizenship 29: 61-74.

Ruiz, M., de los Ríos, A. and Tirado, P. (2009) La responsabilidad social y la crisis económica. ¿Responden las entidades financieras españolas a los grupos de interés?. CIRIEC-España, Revista de Economía Pública, Social y Cooperativa 65: 33-58.

Ruiz, B., Esteban, A. and Gutiérrez, S. (2014) Banking reputation during the economic downturn. Comparison among the leading Spanish financial institutions from the customer's perspective. Universia Business Review 43: 16-35.

Sarro, M.M., Cuesta, P. and Penelas, A. (2007) La responsabilidad social corporativa (RSC): una orientación emergente en la gestión de las entidades bancarias españolas. In Ayala, J.C. (2007), Conocimiento, Innovación y emprendedores: camino al futuro. Universidad de La Rioja.

Schwartz, S.H. (1992) Universals in the content and structure of values: Theoretical advances and empirical test in 20 countries. Advances in Experimental Social Psychology 25: 1-64.

Server, R.J. and Capó, J. (2009) La Responsabilidad Social Empresarial en un context de crisis. Repercusión en las Sociedades Cooperativas. CIRIEC-España, Revista de Economía Pública, Social y Cooperativa 65: 7-31.

Shimp, T.A., Stuart, E.W. and Engle, R.W. (1991) A program of classical conditioning experiments testing variations in the conditioned stimulus and context. Journal of Consumer Research 18(1): 1-12. 
Soto, M. (2006). La responsabilidad social en el sector financiero: el Grupo SCH. Working paper, Fundación Carolina.

Triandis, H.C., Leung, K., Villareal, M.J. and Clark, F.I. (1985) Allocentric versus idiocentric tendencies: Convergent and discriminant validation. Journal of Research in Personality 19: 395415.

Truscott, R., Bartlett, J. and Tywoniak, S. (2009) The reputation of the corporate social responsibility industry in Australia. Australasian Marketing Journal 17(2): 84-91.

van Herpen, E., Pennings, J. and Meulenberg, M. (2003) Consumers' evaluations of socially responsible activities in retailing. Working paper, Wageningen University Marketing and Consumer Behaviour Group, Wageningen.

van Marrewijk, M. (2003) Concepts and definitions of CSR and corporate sustainability: between agency and communication. Journal of Business Ethics 44(2/3): 95-105.

Varadarajan, P.R. and Menon, A. (1988) Cause-related marketing: A coalignment of marketing strategy and corporate philanthropy. Journal of Marketing 52(3): 58-74.

Vitell, S.J., Paolillo, J.G.P. and Thomas, J.L. (2003) The perceived role of ethics and social responsibility: A study of marketing professionals. Business Ethics Quarterly 13(1): 63-86.

Waldman, D., de Luque, M.S., Washburn, N. and House, R.J. (2006) Cultural and leadership predictors of corporate social responsibility values of top management: A GLOBE study of 15 countries. Journal of International Business Studies 37(6): 823-837.

Walsh, G., Mitchell V., Jackson, P.R. and Beatty, S.E. (2009) Examining the antecedents and consequences of corporate reputation: A customer perspective. British Journal of Management 20: $187-203$. 
Wang, F., Zhang, H., Zang, H. and Ouyang, M. (2005) Purchasing pirated software: An initial examination of Chinese consumers. Journal of Consumer Marketing 22(6): 340-351.

Weiner, B. (ed.) (1980) Human Motivation. Hillsdale, NJ: Lawrence Erlbaum Associates.

Yoo, B. (2009) Cross-national invariance of the effect of personal collectivistic orientation on brand loyalty and equity. The United States versus South Korean consumers. Asia Pacific Journal of Marketing 21(1): 41-57.

\section{APPENDIX}

Table 4 about here 
TABLE 1

Justification for the relationships in Rifon's et al. (2004) model

Causal relationship

Congruence $\rightarrow$ Attribution

Congruence $\rightarrow$ Credibility

Attribution $\rightarrow$ Credibility

Congruence $\rightarrow$ CSR Image

Attribution $\rightarrow$ CSR Image

Credibility $\rightarrow$ CSR Image

\section{References}

Rifon et al. (2004); Becker-Olsen et al. (2006); Bigné et al. (2009)

Rifon et al. (2004); Becker-Olsen et al. (2006); Bigné et al. (2009) Rifon et al. (2004); Bigné et al. (2009)

Varadarajan and Menon (1988)

van Herpen et al. (2003)

Bigné et al. (2009) 
TABLE 2

First-order CFA

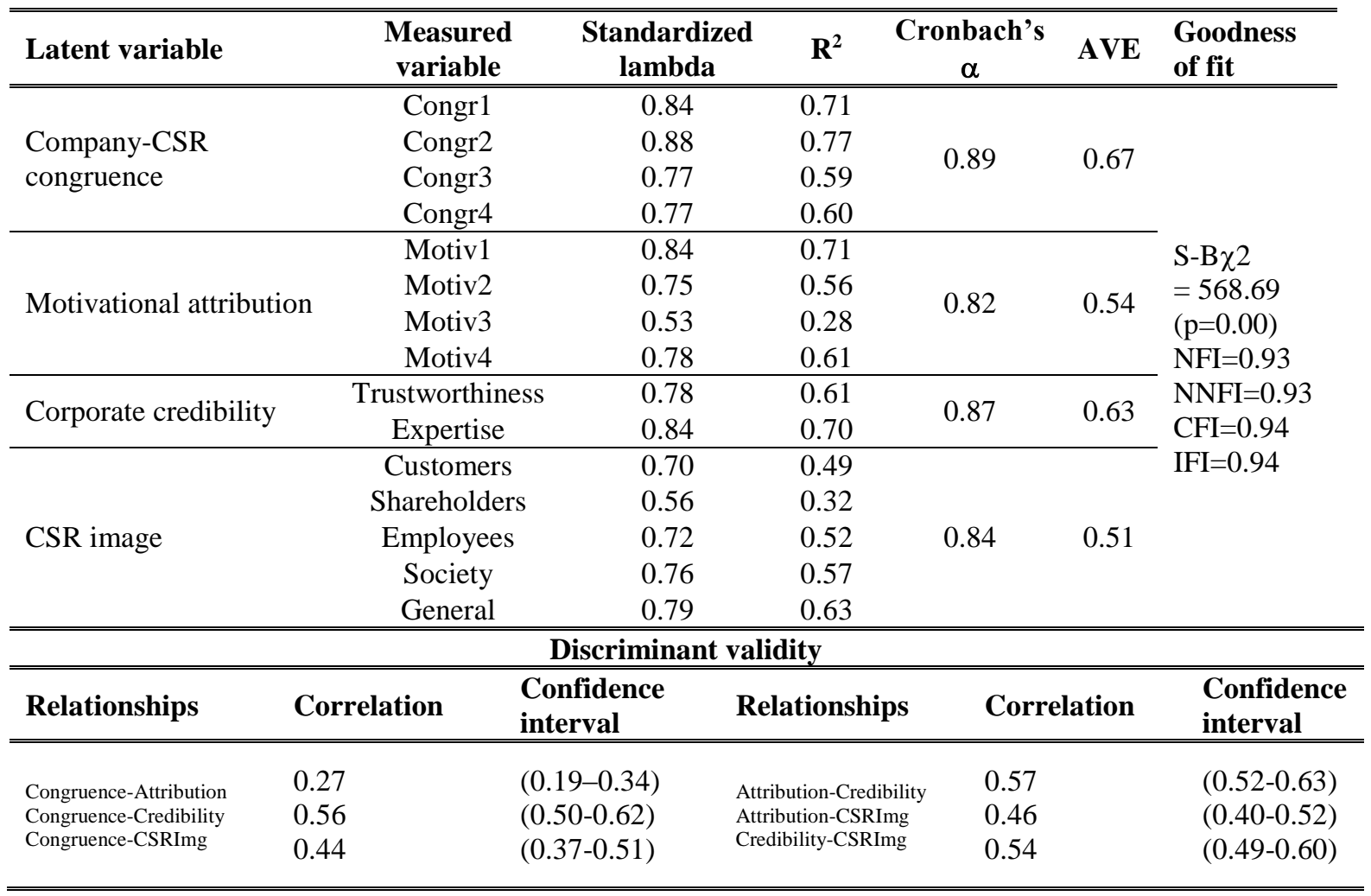


TABLE 3

Hypotheses test (multisampling analyses)

Moderating variable: collectivism

\begin{tabular}{|c|c|c|c|c|c|}
\hline \multirow{2}{*}{ Hypothesis } & \multirow{2}{*}{ Causal relationship } & \multicolumn{2}{|c|}{ Standardized coefficients } & \multirow{2}{*}{ Dif. $\chi^{2}(1)$} & \multirow{2}{*}{ Contrast } \\
\hline & & Individualists & Collectivists & & \\
\hline \multirow{6}{*}{ H1 } & "Congruence $\rightarrow$ Attribution & 0.30 & 0.23 & 0.11 & \multirow{6}{*}{ Accepted } \\
\hline & Congruence $\rightarrow$ Credibility & 0.40 & 0.32 & 0.17 & \\
\hline & Congruence $\rightarrow$ CSRImg & 0.26 & 0.22 & 1.38 & \\
\hline & Attribution $\rightarrow$ Credibility & 0.45 & 0.52 & 0.05 & \\
\hline & Attribution $\rightarrow$ CSRImg & 0.25 & 0.27 & 2.01 & \\
\hline & Credibility $\rightarrow$ CSRImg & 0.09 & 0.27 & - & \\
\hline Fit & \multicolumn{5}{|c|}{$\begin{array}{c}\mathrm{S}-\mathrm{B} \chi^{2}=493.53(\mathrm{p}<0.001) ; \mathrm{NFI}=0.92 ; \mathrm{NNFI}=0.95 ; \mathrm{CFI}=0.95 ; \mathrm{IFI}=0.96 \\
\text { Dif. } \chi^{2}(2)=5.25(\mathrm{p}=0.07)\end{array}$} \\
\hline \multicolumn{6}{|c|}{ Moderating variable: novelty seeking } \\
\hline \multirow{2}{*}{ Hypothesis } & \multirow{2}{*}{ Causal relationship } & \multicolumn{2}{|c|}{ Standardized coefficients } & \multirow{2}{*}{ Dif. $\chi^{2}(1)$} & \multirow{2}{*}{ Contrast } \\
\hline & & Conservative & Innovative & & \\
\hline \multirow{6}{*}{$\mathrm{H} 2$} & "Congruence $\rightarrow$ Attribution & 0.32 & 0.18 & 1.61 & \multirow{6}{*}{ Accepted } \\
\hline & Congruence $\rightarrow$ Credibility & 0.45 & 0.34 & 0.69 & \\
\hline & Congruence $\rightarrow$ CSRImg & 0.30 & 0.21 & $3.50 * *$ & \\
\hline & Attribution $\rightarrow$ Credibility & 0.42 & 0.55 & $3.32 * *$ & \\
\hline & Attribution $\rightarrow$ CSRImg & 0.27 & 0.15 & $8.02 *$ & \\
\hline & Credibility $\rightarrow$ CSRImg & 0.14 & 0.42 & - & \\
\hline Fit & $\mathrm{S}-\mathrm{B} \chi^{2}=474.68$ & $\begin{array}{l}01) ; \mathrm{NFI}=0.93 ; \\
\text { Dif. } \chi^{2}(4)=15.5\end{array}$ & $\begin{array}{l}0.96 ; \mathrm{CFI}=0.9 \\
00)\end{array}$ & $\overline{\mathrm{IFI}}=0.96$ & \\
\hline
\end{tabular}

$*$ p-value $<0.05 ; * *$ p-value $<0.1$ 
TABLE 4

Measurement scales

\begin{tabular}{|c|c|}
\hline Variable & Items \\
\hline $\begin{array}{l}\text { Company-CSR } \\
\text { congruence }\end{array}$ & $\begin{array}{l}\text { 1) Carrying out CSR activities is compatible with this institution's core business; 2) } \\
\text { It makes sense that this institution carries out CSR activities; 3) Carrying out CSR } \\
\text { activities is complementary to this institution's core business; 4) There is a logical } \\
\text { fit between the core business of this institution and the CSR activities that it carries } \\
\text { out }\end{array}$ \\
\hline $\begin{array}{l}\text { Motivational } \\
\text { attribution }\end{array}$ & $\begin{array}{l}\text { 1) Acts unselfishly; 2) Is altruistic; 3) Acts guided by the global benefit of its } \\
\text { stakeholders instead of by its self-interest; 4) Is generous }\end{array}$ \\
\hline $\begin{array}{l}\text { Corporate } \\
\text { credibility }\end{array}$ & $\begin{array}{l}\text { TRUSTWORTHINESS: } 1 \text { ) Has a great expertise in corporate social responsibility; } \\
\text { 2) Is competent in the implementation of its responsibilities towards its stakeholders } \\
\text { EXPERTISE: } 3 \text { ) Its commitment to its stakeholders is credible; 4) Is honest about its } \\
\text { commitment to its stakeholders }\end{array}$ \\
\hline CSR image & $\begin{array}{l}\text { CUSTOMERS: 1) Establishes procedures to comply with customers' complaints; 2) } \\
\text { Treats its customers honestly; 3) Has employees who offer complete information } \\
\text { about corporate products/services to customers; 4) Uses customers' satisfaction as } \\
\text { an indicator to improve the product/service marketing; 5) Make an effort to know } \\
\text { customers' needs } \\
\text { SHAREHOLDERS AND SUPERVISING BOARDS: 6) Tries to maximize its } \\
\text { profits; 7) Keep a strict control over its costs; 8) Tries to insure its survival and } \\
\text { long-term success; 9) Honestly informs about its economic situation to its } \\
\text { shareholders and/or supervising boards } \\
\text { EMPLOYEES: 10) Pays fair salaries to its employees; 11) Offers safety at work to } \\
\text { its employees; 12) Treats its employees fairly (without discrimination or abuses); } \\
\text { 13) Offers training and career opportunities to its employees; 14) Offers a pleasant } \\
\text { work environment (e.g., flexible hours, conciliation) } \\
\text { SOCIETY: 15) Helps solving social problems; 16) Uses part of its budget for } \\
\text { donations and social projects to advance the situation of the most unprivileged } \\
\text { groups of the society; 17) Contributes money to cultural and social events (e.g., } \\
\text { music, sports); 18) Plays a role in the society beyond the economic benefits } \\
\text { generation; 19) Is concerned with improving the general well-being of society } \\
\text { GENERAL: 20) Is concerned with respecting and protecting the natural } \\
\text { environment; 21) Always respects rules and regulations defined by law; 22) Is } \\
\text { concerned with fulfilling its obligations vis-à-vis its shareholders, suppliers, } \\
\text { distributors and other agents with whom it deals; 23) Is committed to well } \\
\text { established ethic principles }\end{array}$ \\
\hline Collectivism & $\begin{array}{l}\text { UNIVERSALISM: 1) I try hard to get a more peaceful and harmonious world; 2) I } \\
\text { believe that equal opportunities for everybody are necessary; 3) I try to prevent } \\
\text { injustices that could transgress social standards and harm other people } \\
\text { BENEVOLENCE: 4) I always try to act in a honest way; 5) I try to contribute to } \\
\text { other people's welfare as much as I can; 6) I am always willing to forgive others }\end{array}$ \\
\hline Novelty seeking & $\begin{array}{l}\text { STIMULATION: 1) I like trying new things; 2) I like having an exciting life } \\
\text { SELF-DIRECTION: 3) I like the challenge of doing something that I have never } \\
\text { done before; 4) In my life, I am always searching for exciting and stimulating things }\end{array}$ \\
\hline
\end{tabular}

Seven-point Likert-type scale (1=strongly disagree with the sentence, $7=$ =strongly agree) 
FIGURE 1

Conceptual model and hypotheses

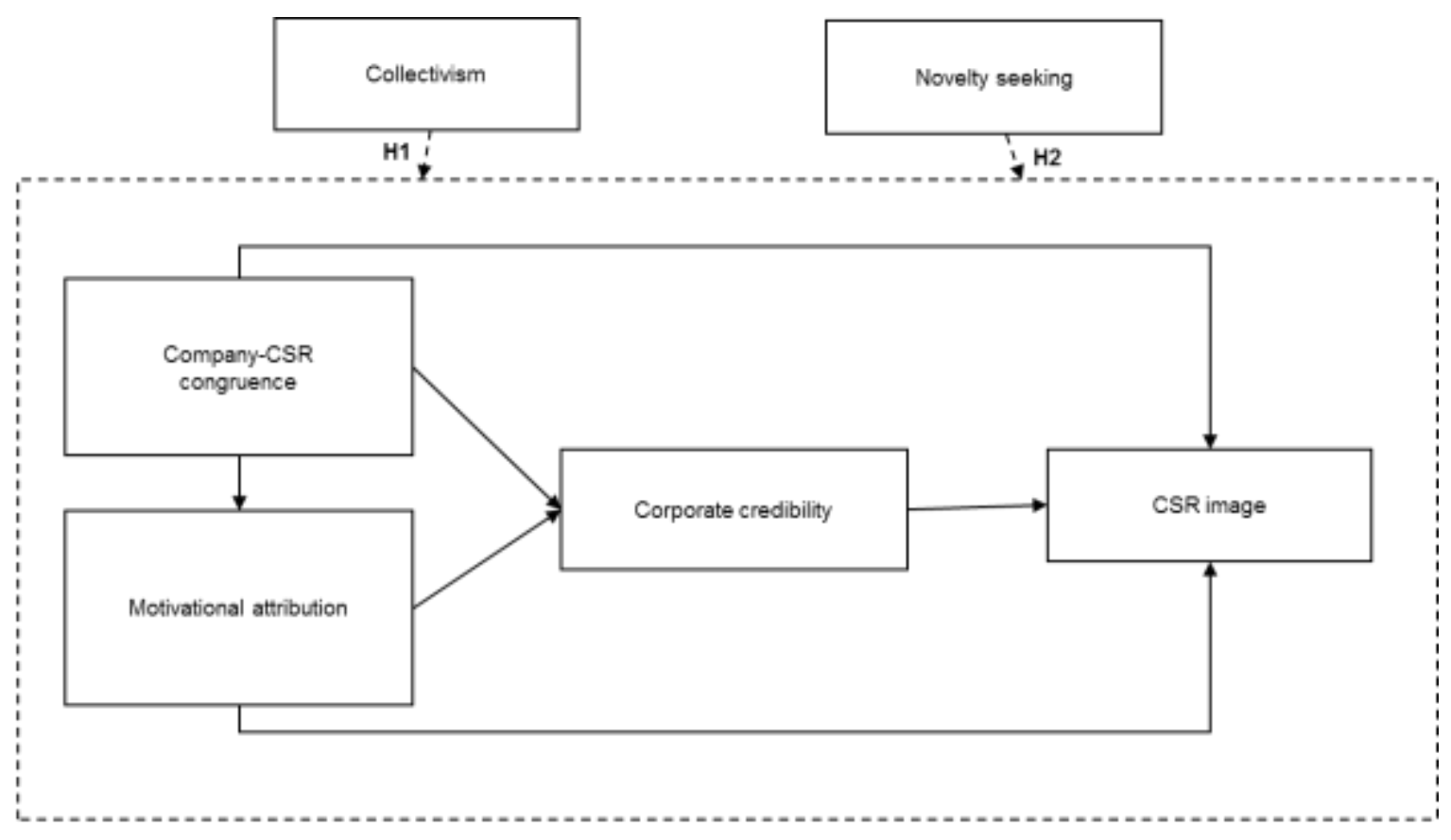

